\title{
Verb-Noun Collocation Proficiency and Academic Years
}

\author{
Fatemeh Ebrahimi-Bazzaz (Corresponding author) \\ Department of English Translation, Islamic Azad University, Tehran North Branch \\ Language College, Bozorograh Shaid Babaei, roberroye Hakimieh, Chamanara Street, Tehran 1651153311, Iran \\ Tel: 98-9123444350 E-mail: fatemehebrahimibazzaz@gmail.com
}

Arshad Abd Samad

Department of Language Education and Humanities Faculty of Educational studies University Putra Malaysia, 43400 UPM Serdang, Selangor Darul Ehsan, Malaysia

Tel: 60-122987424 E-mail: arshad.samad@yahoo.com

Ismi Arif bin Ismail

Head of graduate Office in Faculty of Educational Studies

University Putra Malaysia, 43400 UPM Serdang, Selangor Darul Ehsan, Malaysia

Tel: 60-126381712 E-mail: ismilina@gmail.com

Nooreen Noordin

Department of Language Education and Humanities, Faculty of Educational Studies

University Putra Malaysia, 43400 UPM Serdang, Selangor Darul Ehsan, Malaysia

Tel: 60-136670573 E-mail: nooyeen@yahoo.com

Received: 23-09-2013

doi:10.7575/aiac.ijalel.v.3n.1p.152
Accepted: 05-11-2013

Published: 01-01-2014

URL: http://dx.doi.org/10.7575/aiac.ijalel.v.3n.1p.152

\begin{abstract}
Generally vocabulary and collocations in particular have significant roles in language proficiency. A collocation includes two words that are frequently joined concurrently in the memory of native speakers. There have been many linguistic studies trying to define, to describe, and to categorise English collocations. It contains grammatical collocations and lexical collocations which include nouns, adjectives, verbs, and adverb. In the context of a foreign language environment such as Iran, collocational proficiency can be useful because it helps the students improve their language proficiency.

This paper investigates the possible relationship between verb-noun collocation proficiency among students from one academic year to the next. To reach this goal, a test of verb-noun collocations was administered to Iranian learners. The participants in the study were 212 Iranian students in an Iranian university. They were selected from the second term of freshman, sophomore, junior, and senior years. The students' age ranged from 18 to 35. The results of ANOVA showed there was variability in the verb-noun collocations proficiency within each academic year and between the four academic years. The results of a post hoc multiple comparison tests demonstrated that the means are significantly different between the first year and the third and fourth years, and between the third and the fourth academic year; however, students require at least two years to show significant development in verb-noun collocation proficiency. These findings provided a vital implication that lexical collocations are learnt and developed through four academic years of university, but requires at least two years showing significant development in the language proficiency.
\end{abstract}

Keywords: Language proficiency, Collocation, Communicative Competence, academic year, Iranian EFL learners

\section{Introduction}

Generally vocabulary and collocations in particular have significant roles in language learning. Collocations should be correctly taught and learned; otherwise, the production of wrong collocations results in irregularities which ultimately show the learners' spoken or written language to be awkward and non-native. There have been many linguistic studies trying to define, to describe, and to categorise English collocations. Zhang (1993, p. 13) states that collocations are frequently explained as "conventionalised and prefabricated combinations of two or more words." Collocations have received less attention than grammar and vocabulary even though their number "amounts to tens of thousands" (Shokouhi \& Mirsalari (2010, p. 5). Yet, they have been treated marginally in linguistics (Lipske, 2006), and there are 
"too many fixed expressions for us to simply disregard them as phenomena on the margin of language (Jacendoff, 1995, p. 156).

Collocations in English are discussed within two theoretical traditions which can be placed at the end of two continuums: the lexis-oriented tradition and the grammar-oriented tradition. Linguists following the lexical tradition such as (Firth, 1957a; Halliday, 1966), and Sinclair (1966) proposes that the meaning of words is derived from the words they keep company with while those who follow a more grammar oriented tradition (Greenbaum, 1970, Mitchell, 1971, and Kjellmer, 1984) emphasise the role of syntax as a central determinant in the meanings and the use of collocations.

On the one end of continuum, in the lexis-oriented tradition, Firth (1968) defines collocations of a given word "as statements of habitual or customary places of that word in collocational order but not in any other contextual order and emphatically not in any grammatical order" (p. 181). He also claims that a collocation is a "mode of meaning" and "an abstraction at the syntagmatic level" (1957a). In addition, he observes that part of a word's meaning can be located in its collocate. He proposes that words obtain meaning from their co-occurrence in texts and suggests that a meaning should be examined in four levels: the orthographic level, the phonological level, the grammatical level, and the collocational level. Firth's innovative concept on collocations has drawn researchers to focus not only on the paradigmatic level of collocations but also on the syntagmatic level of collocations.

Firth's concept is echoed by neo-Firthians, the most distinguished of ones are McIntosh (1961), Halliday (1966), and Sinclair (1966). In the 1960's, Halliday (1966) and Sinclair (1966) attempted to research collocations in the same way as grammar. They examined lexis as a linguistic level in parallel with grammar. They proposed that lexical items are selected from lexical patterning as choose grammatical items from a grammatical system that establishes grammatical structure. This notion suggests that a language contains hundreds of thousands of lexical units. McIntosh (1961), furthermore, suggested that the range of collocability of particular items can provide a way of distinguishing words from each other. For example, putrid and rancid are synonymous, but putrid collocates with fish and rancid with butter. Collocations that can collocate widely are normally restricted to certain patterns and are non-substitutable. For example, soft, mild, and gentle can all collocate with voice, breeze or soap, but each word has restricted collocations, such as soft water, soft drink, mild steel, gentle soap, etc. (McIntosh, 1961 cited in Mitchell, 1971, pp. 35-69).

On the other end of the continuum, the grammatical oriented tradition, collocations are perceived as lexical and syntactic patterning which are in interrelated levels of structure. This theory has been proposed since the 1970's. The advocates of this view claim that to study collocations, one should not only focus on the linear and syntagmatic cooccurrence of items, but also on the syntactic and semantic aspects of collocations. As Greenbaum (1970) indicates, "a serious disadvantage of a purely item-oriented approach to the study of collocations is that it obscures syntactic restrictions on collocations." For example much collocates with like in a negative sentence as in I don't like him much but not in an affirmative sentence as in * I like him much (p. 11). Greenbaum proposes that the collocability of words should bond to syntax and suggests that some particular collocations come together only in certain syntactic relationships, as the above example shows.

Supporting a grammatical tradition, Mitchell (1971) criticised the Neo-Firthians for their separation of lexical study from grammar. He also stresses that in order to discover the nature of collocation, grammar and lexis should be studied as one entity and further maintained that meanings of collocations emerge not only from the lexical level but also from grammatical relations within them. He also argues that "lexical particularities are considered to derive their meaning not only from contextual extension of a lexical kind but also from the generalised grammatical patterns within which they appear".

To emphasise more the role of the grammatical tradition, Kjellmer (1984, p. 48) further argued that collocations should be studied in a grammatical framework and defines collocations as "lexically determined and grammatically restricted sequences of words".

It can be argued further that collocations can involve a range of different syntactic patterns. To illustrate this range, Benson, et al., (1997) presented a comprehensive explanation of a categorisation criterion with examples to define what knowing a word means. They also classified collocations into two main types: grammatical collocations (for example, by chance) and lexical collocations (for example, valuable asset). It contains eight main types of grammatical collocations and seven types of lexical collocations. Nevertheless, the authors do not include "free combinations" in their dictionary which are, in effect, limitless. A grammatical collocation is a frequent grouping of a dominant word (verb, noun, adjective) and a grammatical word (preposition), like make up (verb and preposition), concerned about (adjective and preposition), and a choice between (noun and preposition). Typical lexical collocations include nouns, adjectives, verbs, and adverb. Hence, Benson, et al., categorise lexical collocations by structural types: 1 . verb + noun (kick the ball, make a sandwich), 2. adjective + noun (terrible mistake), 3. noun + verb (cars crash), 4. noun $1+$ of + noun 2 (a school of fish), 5. adverb + adjective (closely related), 6. verb + adverb (move slowly).

While both the lexical oriented and grammar oriented traditions related to collocations seem to have their benefits, it is not a matter of which traditions is superior. A lexical oriented tradition emphasises the need to master many collocations as compared to grammar oriented tradition. However, understanding the existence of both traditions allow us to appreciate the complexity of the nature of the collocations and consequently, the potential difficulty in learning collocations for EFL learners. 
Researchers and lexicographers discriminate collocations into different types from various perspectives. The compilers of Oxford Dictionary of Current Idiomatic English, Cowie, Mackin and MaCCaig (1983), use idiomaticity to categorise collocations and idioms into four groups according to idiomaticity from most to least fixed: pure idioms, figurative idioms, restricted collocations, and open collocations. Pure idioms, such as blow the gaff, are the most fixed with semantic opacity. Figurative idioms, such as catch fire and a close shave, are more transparent and not quite fixed. Restricted collocations are collocations that have one element used in a non-literal sense and the other used in its normal meaning, like, under a shadow, while open collocations involve elements which are freely combinable and each element has its literal sense such as a mad dog. It can be concluded that some scholars regard free combinations as collocations and categorises collocations into free collocations and restricted collocations according to their degree of restrictedness.

By the same token, Lewis $(2000$, p. 116) points out, "the type which names a concept, usually verb + noun (move house) or verb + adjective + noun (take the wrong turn)" is the most important collocation type. Typical lexical collocations consist of nouns, adjectives, verbs, and adverbs. As Hill (2003, p. 51) emphasises, "it is the noun which carries most content and it is the noun which is at the centre of most collocations". Furthermore, Lewis (1997a) divides collocations into strong and weak ones according to their fixedness and restrictedness, and distinguishes collocations from frequent and infrequent ones due to their frequency of co-occurrence in a corpus. Strong collocations are recognised as tightly linked phrases that almost function like single words. In contrast, weak collocations, such as a nice day and a good play, are combinations of two ordinary words, and each of them may combine with many other words. Collocations can also be any combination of strong and frequent, strong and infrequent, weak and frequent, or weak and infrequent.

The correlation between collocations and language proficiency has been investigated by many researchers such as Nesselhauf (2005) who described the use of verb-noun collocations by advanced German learners of English in free writing. He collected thirty-two essays and showed there was a correlation between language proficiency and collocational proficiency and the learners' L1 had a great influence on it. He also found that the most frequent collocational error types were associated with the wrong choice of the verb. He assumed that the verb in a collocational group contains a restricted sense (p. 239), and showed that learners' L1 strongly affected students' collocation productions.

Various other studies have also examined collocations from other perspectives. E.g., Al-Zahrani, (1998), Bahns \& Eldaw (1993), and Howarth (1998a) looked at verb + noun collocations, Chi, Wong, and Wong, (1993) and Fan (1991) worked on delexical verbs, and Granger (1998) and Lorenz (1999) examined adverb + adjective collocations. Nevertheless, these studies do not emphasise collocations as belonging to one category or another and in fact, deal with very specific aspects of collocations. Some, for example Chi et al. and Fan (1991) focus on rather discrete aspects such as delexicalised verbs, which do not have immediate importance to this study because of its limited relevance.

There are numerous researchers studying learners' collocational proficiency, but among them, Al-Zahrani (1998) discovered that there was a significant difference in subjects' performance according to their academic levels. The findings were stressed by Nesselhauf (2005), who illustrated that learners' L1 strongly affected their collocation productions. The most recent works were performed by Martyska (2004), their results coincide with those obtained by previous scholars that most of collocational errors resulted from negative LI transfer. The Martyska's study (2004) also found that intermediate high school students knew 55\% of all collocations in four different tasks, and verb-noun collocations seemed to be relatively easier than other types of lexical collocations under investigation for this group of subjects. Martyska also emphasised the important role of the teacher and the textbooks in the process of second language teaching. Both Al-Zahrani's study and Martyska's study imply that exposure to the target language as well as academic maturity may have direct influence on the acquisition of collocations. This is not surprising as the complex nature of collocations as discussed in the previous sections may make them rather difficult to teach in formal classroom situations.

\section{Collocation Studies in Iran}

There are a few studies on collocations in Iran. The first was done by Tajalli (1994) who worked on translatability of English and Persian collocations. He found out that first the main source of difficulty was that students were not familiar with English collocations owing to inadequate exposure. Second, non-congruent grammatical structures of English and Persian collocations were not responsible for possible constraints. Third, some problems may be related to the insufficient proficiency of the full semantic potential of simple lexical items when united to form collocations. Fourth, the experiment showed that the use of collocations was affected by the presence or absence of direct translational equivalence which significantly influences translatability. Finally, it was noticed that some problems were related to lack of sufficient familiarity with Persian collocations.

Unlike Tajalli, Morshali (1995) performed comprehensive research on the learning of English lexical collocations by Iranian EFL learners. Her study found out that first, the Iranian EFL learners' proficiency of collocations was far behind their proficiency of vocabulary. Second, there was no significant relationship between the level of language proficiency and that of the proficiency of English collocations. Third, the Iranian learners did not normally learn collocations without formal teaching. Finally, the number of collocational errors made by the Iranian EFL learners highlighted the need for formal teaching of collocations (1995: iv). 
Hasan Abadi's study (2003) was different from Morshali (1995) because he performed a research on both grammatical and lexical collocations. His subjects were 80 Iranian EFL learners at Shiraz University. The Test of Collocations consisted of forty items. He found out that there was a significant relationship between the performance of the learners on lexical and grammatical collocations. There was also a significant difference between the performances of the learners on different subcategories of collocations.

Faghih and Sharafi (2006) focussed on the another aspect of collocations because they worked on the impact of collocations on Iranian EFL learners' inter-language and an error pattern in the vocabulary of Iranian EFL learners, namely the confusion of collocations. Their results showed that collocation confusion was really a common error in the inter-language of Iranian EFL learners. There was also a positive correlation between students' overall proficiency and their proficiency of collocations; they did not have difficulties with all kinds of collocations, but adjective-noun collocations caused the most problem for them.

Unlike Faghih and Sharafi' (2006), Koosha and Jafarpour (2006) used concordancing materials through data-driven learning (DDL) to observe its effect on the teaching or the learning of collocation of prepositions, to discover whether collocational proficiency of prepositions could be examined at the different levels of EFL students' proficiency, and to find out how much Iranian EFL collocational proficiency of prepositions is influenced by their mother tongue. To reach this aim, they selected two hundred senior English major students from three universities in Sharkord. Subjects were given a Michigan Test of English Language Proficiency to determine the subjects' level of language proficiency. There were two completion tests on collocations of prepositions as the pre-test and post-test to check the effects of the treatments. The results indicated that the DDL approach was extremely useful in the learning and teaching, and subjects' performance in the test of collocation preposition was proved to be positively related to their level of language proficiency. Finally, error analysis of collocations showed that Iranian EFL learners transferred their L1 collocational patterns to their L2 production.

Bagherzadeh Hosseini and Akbarian's (2007) study is different from the above mentioned studies because they investigated the relationship between collocational competence and general language proficiency and examined the gotogetherness of quantitative and qualitative characteristics of lexical proficiency. The subjects were selected from thirty senior students in two Iranian universities through a tailored TOEFL test. An MC test of noun-verb collocations was administered to the subjects. The results indicated that there was a relationship between the collocation test and TOEFL and between the vocabulary section of TOEFL and the collocation test. Moreover, subjects' qualitative proficiency went with their quantitative proficiency. It can be concluded that collocation had to be taught at the right time through explicit teaching to make students aware of collocations.

Keshavarz and Salimi's (2007) instruments were different from Bagherzadeh Hosseini and Akbarian (2007) as they employed open-ended, multiple choice cloze tests, and TOEFL to measure collocational competence and language proficiency of one hundred Iranian students. A TOEFL test evaluated the subjects' language proficiency and a fifty item test comprising lexical and grammatical collocations examined their collocational proficiency. They found out that there existed a significant relationship between performance on cloze tests and collocational competence. The results also pointed out that collocational competence was very important to increase language proficiency of Iranian EFL learners in the target language.

Unlike Keshavarz and Salimi's study (2007), Ghonsooli, Pishghadam, and Mohaghegh Mahjoobi (2008) performed research on the effect of teaching collocations on Iranian EFL learners' English writing. They employed quantitative and qualitative methods in two stages, a product phase and a process phase. To this end, thirty subjects from the English Department of the College of Ferdowsi University in Iran were selected. They were taught their course materials in twenty one sessions. The experimental group were seventeen students to whom collocations were taught by different techniques. However, the control group was taught through the conventional slot and filter approach. The results showed that the experimental group had a higher mean score in their collocation test and English Writing Test at the product stage because of collocation teaching. Their mean scores for different writing section demonstrated that subjects' vocabulary and fluency increased considerably as a result of collocation teaching at the process stage.

Sadeghi (2009) studied the collocational differences between L1 and L2 and its implications for EFL learners and teachers. His study was different from Ghonsooli, Pishghadam, and Mohaghegh Mahjoobi's (2008) study since he used a comparative method and compared collocations between Persian and English. There were seventy six students who participated in a sixty item Persian and English Test of Collocations. The results showed students might have a lot of problems in using collocations where they negatively transferred their linguistic proficiency of Persian to English.

Shokouhi and Mirsalari (2010) also performed research on the relationship between collocational proficiency and general linguistic proficiency among EFL learners. There were thirty five subjects who were chosen by a proficiency test and were administered a 90-item multiple-choice test which had lexical collocations: noun-noun, noun-verb, and adjective-noun, and grammatical collocations: noun-preposition, and preposition-noun. The results demonstrated that there was no significant correlation between the general linguistic proficiency and collocational proficiency of EFL learners, and lexical collocations are easier than grammatical collocations for the students and from among all subcategories, noun-preposition was the most difficult and noun-verb was the easiest.

Unlike the mentioned studies, Bazzaz and Samad (2011) discussed the relationship between collocational proficiency and the use of verb-noun collocations in writing stories since collocational proficiency differentiates native speakers and foreign or second language learners and is a major issue in productive skills especially writing. To this end, twenty 
seven Iranian PhD students in a Malaysian university were selected. The students' proficiency was measured by a special constructed C-Test and the use of collocations was calculated by the number of collocations that was used by the students in their essays. To reach this end, students wrote six different stories in six weeks based on a written task in which verb-noun were elicited. The results indicated that there was a large positive relationship between proficiency of collocations and the use of verb-noun collocations in the stories.

Bahardoust (2012) also performed a research on the rate of lexical collocations in Iranian EFL learners' writing production between L1 and L2, and the influence of L1 on L2 collocational use. To reach this aim, two hundred subjects were chosen. The data was collected from midterm, final tests, and assignments of the students. The data was analysed by chi-square, and the rate of lexical collocations was estimated. Moreover, the rate of different groups of lexical collocations was compared. The results showed that the rates of verb-noun and adjective-noun were the highest, and the rate of noun-verb was the lowest. The rate and the frequency of collocations were compared in L1 and L2 paragraphs. The results discerned that L1 collocations had higher rate and frequency than L2, and L1 produced both positive and negative influence on collocations.

Ganji (2012) went one step further from aforementioned research and studied the relationship between gender and academic years of Iranian EFL learners' collocational proficiency. He discussed the collocational proficiency of students at the three academic levels of freshman, sophomores, and junior. To this end, forty three English major subjects were selected from English Translation studies in Chahbahar Maritime University. They participated in a 50item fill in the blank Test of Collocations in which five types of lexical collocations: verb-noun, adjective-noun, nounverb, adverb adjective, and verb adverb were tested. The results showed that Iranian English major students were weak in lexical collocations because they answered just more than $50 \%$ of the questions. There was a significant difference in the performance of the students at the three academic levels; however, no significant difference was observed between girls and boys in their collocational proficiency. The finding also indicated that noun-verb collocations were the easiest type, but the adverb adjective collocations were the hardest ones.

The aforementioned studies in Iran discuss the different collocational proficiency of students and language proficiency; however their results are contradictory because some found that students' collocational proficiency improve as their language proficiency increases such as Bazzaz and Samad (2011), Ganji (2012) and Keshavarz and Salimi's (2007) while the others indicate that there is no relationship between collocational proficiency and language proficiency like Shokouhi and Mirsalari(2010) and Morshali (1995). Other studies worked on language transfer from L1 and found out that students use collocations incorrectly because of negative transfer and lack of exposure (Koosha and Jafarpour, 2006; Sadeghi, 2009; \&Tajalli, 1994).

The correlation between collocations and language proficiency has been investigated by many researchers such as Nesselhauf (2005) who described the use of verb-noun collocations by advanced German learners of English in free writing. He collected thirty-two essays and showed there was a correlation between language proficiency and collocational proficiency and the learners' L1 had a great influence on it. He also found that the most frequent collocational error types were associated with the wrong choice of the verb. He assumed that the verb in a collocational group contains a restricted sense (p. 239), and showed that learners' L1 strongly affected students' collocation productions.

Similarly, Shehata (2008) studied how advanced Arabic-speaking learners of English use English collocations. Ninetyseven subjects sat for two production tests and one reception test dealing with collocations. The data analyses showed that learners' L1 and their learning environment had a strong influence on the acquisition of L2 collocations. Furthermore, the findings revealed that there was a moderate positive correlation between learners' proficiency of collocations. It can be concluded that students' productive proficiency of collocations was inferior to their receptive proficiency of collocations.

Conversely, Zinkgräf, (2008), and Liao (2010) investigated the collocational errors which were the result of negative LI transfer. Their results concur with the findings of Martynska (2004) that most of collocational errors resulted from negative LI transfer. They emphasised the important role of collocations which do not have equivalent in the mother tongue, and the significant teachers' role to facilitate the learning of collocations.

Thus, the research on collocations reviewed so far includes a wide range of discussion from the measure of collocational proficiency to types of collocational errors. These topics seem not to shift from one decade to another, and researchers retain an on-going interest in exploring collocations in the field. Moreover, the empirical studies on collocations attempt to examine learners' collocational proficiency, learners' development of collocations, pedagogical aspects of collocations, and types of collocational errors.

The importance of learning collocations was discussed, and now it can be argued whether teaching collocations is significant or not. Some researchers and language teachers have stressed the importance of teaching collocations. Yet others recommend that collocations, which have no equivalents in learners' LI, deserve more attention (Al-Zahrani, 1998; Bahns \& Eldaw, 1993; Biskup, 1992; Gitsaki, et al., 1999). Therefore, language teachers should be careful in selecting collocations that may cause learners trouble and difficulties. Hill (2000) also advocates that "mediumstrength" collocations between strong and weak collocations should be given priority in expanding learners' mental lexicons, and indicates that not only new collocations but also extension of learned words should be taught. Teachers should play an important role in helping students notice and identify collocations in texts. As Woolard (2000) mentions, as a teacher, he usually tries to draw his students' attention to the surrounding co-text and follow a supplementary 
exercise to activate the learned language chunks. The above literature review shows that verb-noun collocations indeed merit the attention of linguists and language educators.

\section{The present study}

A review of literature shows that there is a need to do research on the relationship between EFL learners' verb-noun collocational proficiency and their academic years. However, a number of studies have discussed the relationships between language proficiency and academic years which is closely related to the topic of this study. Al-Zahrani (1988) found that there is a high correlation between language proficiency and academic years among EFL Saudi students. Gitsaki's (1999) study was on the knowledge of collocations from a developmental perspective. Gitsaki measured the collocational knowledge among 275 Greek learners of English in their junior high school, and they were at three proficiency levels. Al-Zahrani's (1998) study was different from Gitsaki's (1999) in which he measured the collocational knowledge among 81 male Saudi Arabian learners of English in their university, and they were at four proficiency levels.

The present study adds to and expands those previous studies but tries to fill the gap by measuring the relationship between language proficiency and four academic years of EFL learners in Iran. It raises the following research questions:

- Is there a significant difference in the proficiency of verb-noun collocations among

EFL students from one academic year to the next?

\section{Method}

\subsection{Participants}

There were 212 participants in this study. They were four groups of English major students in the English Department in Tehran in April 2010. They were selected from the second term of freshman, sophomore, junior, and senior. There were 44 males and 168 females who were between 18-35 at the time of the study. All of them spoke Persian as their mother tongue. In the test session, a demographic questionnaire, and a blank-filling collocation test were administered to students. The research design utilised in this project is a Cross-sectional design and involves the collection of quantitative data; however, the main shortcoming in the Cross-sectional design which involves quantitative data is the lack of the randomised sampling process and the researcher uses the four intact groups of participants. To overcome this shortcoming, the groups were selected through cluster sampling from the second terms of freshman, sophomore, junior, and senior to collect the data.

Krejcie and Morgan's (1970) Table was used to calculate identical sample sizes in all cases where the researcher alters the $t$ value utilised based on population size and knows the populations. Based on this formula, the population of this study was 480 and the required sample size of the study was determined as two hundred fourteen, but as in most of research, $10 \%$ is added to that number in case some students would not like to participate in the study. Therefore, two hundred thirty five students were selected from four intact groups of male and female students. However, some students withdrew from the experiment in the three phases, leaving a final total of two hundred and twelve students. All groups were selected through cluster sampling from the second term of freshman, sophomore, junior, and senior years. Therefore, participants in the present study belonged to four groups which represent each academic level. Group 1 comprised fifty one students in the second term of their freshmen year. Group 2 included forty seven students in the second term of their sophomore year, Group 3 consisted of sixty four students in the second term of their junior year, and Group 4 comprised fifty students from the second term of their senior year. All respondents were Iranian nationals and native speakers of Persian.

\subsection{Instruments}

The instruments of this study were a demographic questionnaire and a C-test. In this study, a traditional C-Test is used as the test of collocation. In the traditional C-Test, the second half of every key word in a phrase is deleted, leaving the first and last sentence of the passage intact. With the C-Test, a clue (half the word) serves as a stimulus for respondents to find the other half. In this version of the C-Test, only the first letter of every deleted word was provided, for instance, "m__ bed," "s___ tea," or " k__ the ball" in order to elicit the specific collocations intended for this research and to lessen the chance of guessing by subjects (Eckes, 2006; Klein-Braley, 1985; 1997). There is a numerous empirical evidence which supports a positive overall evaluation of C-Tests as tests of general language proficiency. For example, in their work on an English C-Test, Dörnyei and Katona (1992, p. 203) pointed out:

"The C-Test proved to be a highly integrative and versatile measuring instrument, working well in samples of various difficulty and homogeneity levels ... our conclusion about the C-Test is that not only is it a reliable and valid measure of general language proficiency, but it is also one of the most efficient language testing instruments in terms of the ratio between resources invested and measurement accuracy obtained."

Therefore, C-Tests require the combination of skills and knowledge, a core competence in all types of language use. Furthermore, Read (2000) argues that lexical competence is needed in the processing of tests such as Cloze Tests and $\mathrm{C}$-Tests as both knowledge of individual words and the ability to use contextual clues to find out which word fits a blank is required.

The use of the C-Test in this study is also based on previous studies (Al-Zahrani, 1998; Herbst, 1996; Shei \& Pain, 2000; Sung, 2003; Zhang, 1993). There were 50 blanks in the C-Test used in this study. 
Al-Zahrani (1998), for example, used the C-Test and reasoned that giving the first phoneme activates the targeted collocations in the students' mind. These combinations are stored as chunks in their brains and by seeing the first letter; the students can retrieve them from their memories. C-Test does not permit guessing. Finally, the blanks could also be completely filled with one verb which provided a greater validity to his test because it measured the students' knowledge of collocations more precisely. The test items in the C-Test used in this study included only lexical collocations or more precisely verb-noun collocations. The C-test was was piloted on 30 students in the university. They were all English major students. The responses attained from the pilot study were carefully reviewed. It was found that some items were whether too easy or too difficult for students; therefore, they were changed and piloted again on the 30 different students there. Consequently, the modified version of the C-test was used.

The reliability for the C- test was estimated by Cronbach's alpha which was .87 . The result shows that the C-Test has a high reliability and can be utilised to measure the difference in means between verb-noun collocation proficiency of the EFL students and their academic years.

Validity of the test is as important as its reliability; therefore, to validate the modified test of the study, it was administered to a different group of 30 students to measure concurrent validity of the test which was .82 at $p=.01$. The item facility and item discrimination were calculated to keep the appropriate items in the test. Items facility for the Test of Collocations fell within the range of (.47 and .70 respectively) which means the items were not very easy neither too difficult and were in suitable degree of difficulty and can be used to measure students' collocational proficiency (see Brown, 2003).

\subsection{Data Analysis}

To answer the research question, a One-Way Analysis of Variance (ANOVA) was used. The results of the One-Way ANOVA showed there is variability in the proficiency of lexical collocations within each academic year and between the four academic years. Table 1 shows the descriptive results.

Table 1. Summary Table of the Differences among the Four Academic Years in the Test of Collocations

\begin{tabular}{|c|c|c|c|c|c|c|c|c|}
\hline & \multirow[b]{2}{*}{$\mathrm{N}$} & \multirow[b]{2}{*}{ Mean } & \multirow[b]{2}{*}{ SD } & \multirow[b]{2}{*}{ SE } & \multicolumn{2}{|c|}{$95 \%$ CIM } & \multirow[b]{2}{*}{ Minimum } & \multirow[b]{2}{*}{ Maximum } \\
\hline & & & & & LB & UB & & \\
\hline First & 51 & 61.57 & 9.83 & 1.376 & 58.80 & 64.33 & 50.00 & 85.00 \\
\hline Second & 47 & 66.74 & 8.40 & 1.23 & 63.28 & 68.21 & 50.00 & 80.00 \\
\hline Third & 64 & 69.76 & 8.04 & 1.00 & 67.76 & 71.77 & 55.00 & 85.00 \\
\hline Fourth & 50 & 74.50 & 8.46 & 1.20 & 72.09 & 76.90 & 60.00 & 90.00 \\
\hline Total & 212 & 68.02 & 9.81 & .674 & 66.70 & 69.35 & 50.00 & 85.00 \\
\hline
\end{tabular}

Key: $\quad$ CIM $=$ confidence interval of mean

$\mathrm{SD}=$ standard deviation

$\mathrm{SE}=$ standard error

$\mathrm{LB}=$ lower bound

$\mathrm{UB}=$ upper bound

Table 1 shows gradual and generally consistent increase in mean score from one year to the next. The increase is seen to be greater between the first and the second years than the second and the third years. Fourth year students' mean scores are higher than the third year students'; this suggests a high increase similar to that between the first and second year students.

To observe the variability in the verb-noun collocations proficiency within each academic year and between the four academic years, ANOVA was utilised. The results of ANOVA are depicted in Table 2 that shows there is the variability between-group and within-group in the proficiency of collocations.

Table 2. One-Way Analysis of Variance for the Proficiency of Collocations

\begin{tabular}{llllll}
\hline & Sum of Squares & df & Mean Square & F & Sig. \\
\hline Between Groups & 4660.494 & 3 & 1553.498 & 20.637 & 0.000 \\
Within Groups & 15657.430 & 208 & 75.276 & & \\
Total & 20317.925 & 211 & & & \\
\hline
\end{tabular}

Table2, clearly shows that there was a significant difference in the proficiency of lexical verb-noun collocations both between and within the four academic years, $F(3,208)=20,637$ at the $p=.0001$ level which is much less than $\alpha=.05$. 
After the results of the One-Way ANOVA were acquired a post hoc multiple comparison test was carried out by using Tukey's Honestly Significant Difference (HSD) in order to find out which pairs of means were significantly different from each other. Table 3 shows the multiple comparisons of the means of the four academic years in collocation test performance.

Table 3. Multiple Comparisons of the Means of the four Academic Years in the Test of Collocations

\begin{tabular}{lllllll}
\hline (I) grade & (J) grade & MD & SE & Sig. & \multicolumn{2}{l}{$95 \%$ Confidence Interval } \\
\cline { 5 - 7 } & & (I-J) & & & LB & UB \\
\hline \multirow{2}{*}{ First } & Second & -4.17605 & 1.75432 & 0.084 & -8.72 & .37 \\
\cline { 2 - 6 } & Third & $-8.19700^{*}$ & 1.62855 & 0.000 & -12.41 & -3.98 \\
\cline { 2 - 7 } & Fourth & $-12.93137^{*}$ & 1.72671 & 0.000 & -17.40 & -8.46 \\
\hline \multirow{2}{*}{ Second } & Third & -4.02094 & 1.66668 & 0.078 & -8.34 & .29 \\
\cline { 2 - 7 } & Fourth & $-8.75532^{*}$ & 1.76271 & 0.000 & -13.32 & -4.19 \\
\hline Third & Fourth & $-4.73438^{*}$ & 1.63759 & 0.022 & -8.97 & -.49
\end{tabular}

$\mathrm{LB}=$ lower bound

$\mathrm{UB}=$ upper bound

$\mathrm{MD}=$ mean of difference $(\mathrm{I}-\mathrm{J})$

$\mathrm{SE}=$ standard error

Table 3 reveals that the means are significantly different when first year is compared with the third and fourth years in the test of collocation at $\alpha=0.05$, but there is no difference between the first and the second year.

From Table 3, it is evident that for the second year and the third year students, there is no difference at $\alpha=.05$. On the other hand, there was a significant difference between the mean score of second year and the fourth year as shown by significant level $p=.0001$. Alternatively, the difference in the mean score of third and fourth years, Table 3 represents a significant difference at $p=.022$.

As for the no significant differences found between the performance of the students in the second and third years in the Test of Collocations, it may be argued that students' proficiency of collocations may not have improved or it may be related to factors such as the test complexity and testing conditions.

\section{Discussion and Pedagogical Implication}

Regarding the research question, the results from one-way ANOVA demonstrated that there were significant differences both between-groups and within-groups in the verb-noun collocations and the academic years. Afterwards, Tukey test was utilised to find out which pairs of means were significantly different from each other. There was a significant difference between the first, the third and the fourth years and between the mean score of second year and the fourth year, but there was no significant difference between the first and the second year students, between the second year and the third year students. It can be concluded that such statistically significant differences obviously indicate the increase in the students' verb-noun collocation proficiency through the academic years. These findings support the findings of Gitsaki (1999) and Al-Zahrani (1998) who prove that students' knowledge of collocations improve through their academic years.

The result also implies that implicit learning has taken place despite of not receiving any formal and direct teaching of collocations; the students have shown a gradual increase in their knowledge of collocations. While increased knowledge in collocations may be due to exposure to the language both inside and outside the classroom, this does not mean that there is no need for formal learning. The results show that significant difference was mostly in non-consecutive years i.e. at least two year interval in the academic years of students. Therefore, the teaching of verb-noun collocations in formal classroom settings can play a facilitative role and expedite the process of developing verb-noun collocational knowledge. The results of the present study show that the acquisition of collocations and students' knowledge of collocations increased through their academic years that support input flood technique which is an implicit technique and can help students acquire collocations effectively through exposure inside and outside classroom.

The results of the research question add to the current body of research on collocation proficiency. First, the study considers the use of the academic year as an independent variable to assess students' collocational proficiency. The results showed that students' collocational proficiency can adequately be measured through their academic years.

Second, the ability of the students to acquire verb-noun collocational knowledge without learning the collocations through formal instruction provides insights into the role of informal language exposure in language development both inside and outside the classroom. In other words, students did not receive any formal and direct teaching of collocations; they have shown a gradual increase in their knowledge of collocations. Finally, the findings indicate that students may have gained collocation proficiency as part of their communicative competence to communicate effectively in English. 
The results of this study show that there is a difference in the collocation proficiency of EFL Iranian students and their academic years; however, future research in bigger scale may be needed to compare the differences in collocation proficiency both in undergraduate and postgraduate students through their academic years. In this paper, the C-test was used to measure the verb-noun collocations; nevertheless, other test forms can be devised to measure both lexical and grammatical collocations among EFL students in Iran.

\section{References}

Al-Zahrani, M. S. (1998). Knowledge of English lexical collocations among male Saudi college students majoring in English at a Saudi university: Unpublished doctoral dissertation Indiana University of Pennsylvania., Pennsylvania.

Bagherzadeh Hosseini, M . S. \& Akbarian, I. (2007). Language Proficiency and Collocational Competence. The Journal of Asia TEFL, 4(4), 35-58.

Bahardoust, M. (2012). Lexical Collocations in Writing Production of EFL Learners: A Study of L2 Collocation Learning.Iranian EFL Journal, 8(2), 185-200

Bahns, J. (1993). Lexical collocations: a contrastive view. ELT journal, 47(1), 56.

Bahns, J., \& Eldaw, M. (1993). Should we teach EFL learners collocations? .System, 21(1), 101-114.

Bazzaz, F., \& Samad, A. (2011). The Use of Verb-noun Collocations in Writing Stories among Iranian EFL Learners.English Language Teaching, 4(3), 158-163.

Benson, M. (1985).Lexical combinability.Research on Language \& Social Interaction, 18(1), 3-15.

Benson, M., Benson, E., \& Ilson, R. (1997).The BBI combinatory dictionary of English: a guide to word combinations: John Benjamins Publishing Co.

Biskup, D. (1992). L1 influence on learners' rendering of English collocations.In P. A. H. Bejoint (Ed.), Vocabulary and applied linguistics (pp.85-93). London: McMillan.

Biskup, D. (1992). Ll influence on learners' renderings of English collocations: A Polish/German empirical study. In P. L. A. H. Bejoint (Ed.), Vocabulary \& applied linguistics. Houndmills, Basingstoke, Hampshire: Macmillan Academic \& Professional Ltd.

Brown, J. D. (2003). Norm-referenced item analysis (item facility and item discrimination). Statistics, 7(2).

Chi, A. M. L., Wong, K. P., \& Wong, M. C. (1993).Collocational problems amongst ESL learners: a corpus-based study. Paper presented at the corpus linguistics and lexicology, Language Centre, HKUST, Guangzhou and Hong Kong.

Cowie, A. P., Mackin, R., \& MaCCaig, I. R. (1983).Oxford dictionary of current idiomatic

Decarrico, J. S. (2001). Vocabulary learning and teaching.Teaching English as a second or foreign language, 3, 285299.

Erman, B., \& Warren, B. (2000).The idiom principle and the open choice principle.Text-Interdisciplinary Journal for the Study of Discourse, 20(1), 29-62.

Faghih, E. \& Sharafi, M. (2006).The Impact of Collocation on Iranian EFL learners Interlanguage. Science and Research Quarterly, 16, 58.

Fan, M. Y. (1991).A study of the company kept by a selection of English delexical verbs and the implications for the teaching of English in Hong Kong University of Durham, UK.

Firth, J. (1957a).Papers in linguistics 1934-1951. London: Oxford University Press.

Firth, J. (1957b). A synopsis of linguistic theory 1930-55 Studies in Linguistic Analysis. In F. Palmer (Ed.), Selected papers of J. R. Firth 1952-59 (Vol. Special Vol,) 168-206. Bloomington London: Indiana University Press.

Firth, J. R. (1968). A synopsis of linguistic theory,1930-55. In F. R. Palmer (Ed.), Selected papers of J. R. Firth, 19521959. Bloomington: Indiana University Press.

Firth, J. R., \& Palmer, F. R. (1968).Selected papers of JR Firth 1952-1959: Indiana University Press.

Firth, A., \& Wagner, J. (1997). On discourse, communication and (some) fundamental concepts in FLA research.The Modern Language Journal, 81, 285-300.

Ganji, M. (2012).On the Effect of Gender and Years of Instruction on Iranian EFL Learners' Collocational Competence.English Language Teaching, 5(2), 123-133,

Gitsaki, C. (1999). Second language lexical acquisition: A study of the development of collocational knowledge: International Scholars Publications.

Gitsaki, C., Daigaku, N. S., \& Taylor, R. P. (1999).English collocations and their place in the EFL classroom.

Available at: http://www.hum.nagoya- cu.ac.jp/ taylor/ publications/collocations.html.

Ghonsooli, B., Pishghadam, R. \& Mohaghegh Mahjoob, F. (2008). The Impact of Collocational Instruction on the Writing Skill of Iranian EFL Learners: A Case of Product and Process Study. Iranian EFL Journal, 2(1), 36-59 
Granger, S. (1998). Prefabricated patterns in advanced EFL writing: collocations and formulae. Phraseology: Theory, analysis, and applications, 145-160.

Granger, S. (2004). Computer learner corpus research: current status and future prospects. Language and Computers, 52(1), 123-145.

Greenbaum, S. (1970). Verb-intensifier collocations in English: An experimental approach: Mouton.

Halliday, M. (1966).Lexis as a linguistic level.In C. Bazell, J. Catford, M. Halliday \& R. Robins (Eds.), In memory of J. R. Firth 148-162. London: Longman.

Hasan Abadi, S. (2003). A Study of the Learning of English Lexical and Grammatical Collocations by Iranian EFL Learners ,Tabriz College of Letter and Humanities Journal 187, 45-60. http://www.noormags.com/view/fa/ArticlePage/82223

Hill, J. (2000). Revising priorities: from grammatical failure to collocational success. In M Lewis (Ed.), Teaching collocation: further development in the lexical approach.Language Teaching Publications, Hove, UK.

Hill, J. (2003). The place of collocation in the syllabus.In Selected Papers from the Twelfth International.Symposium on English Teaching. 81-86.

Howarth, P. (1998a). Phraseology and second language proficiency.Applied Linguistics, 19(1), 24.

Howarth, P. (1998b). The phraseology of learners' academic writing.In Phraseology: Theory, analysis, and applications, (pp. 161-186).

Hsu, J.T. \& Chiu, C. (2008). Lexical Collocations and their Relation to Speaking Proficiency of College EFL Learners in Taiwan.Asian EFL Journal.

Jacendoff, R. (Ed.). (1995). The boundaries of the lexicon. Hillsdale, NJ: Lawrence Erlbaum Associates, Inc.

Keshavarz, M. H., \& Salimi, H. (2007). Collocational competence and cloze test performance: a study of Iranian EFL learners. International Journal of Applied Linguistics, 17(1), 81-92.

Kjellmer, G. (1984). Some thoughts on collocational distinctiveness. In J. Aarts \& W. Meijs (Eds.) Corpus Linguistics Recent Developments in the Use of Computer Corpora in English Language Research.Amsterdam: Rodopi.

Koosha, M., \& Jafarpour, A. A. (2006). Data-driven learning and teaching collocation of prepositions: the case of Iranian EFL adult learners. The Asian EFL Journal, 8(4), 192.

Lewis, M. (1997a).Implementing the lexical approach: Putting theory into practice.. London: Language Teaching Publications.

Lewis, M. (1997b). Pedagogical implications of the lexical approach.In J. Coady and T. Huckin (Ed.), Second language vocabulary acquisition: A rationale for pedagogy, (p. 255). Cambridge: Cambridge University Press.

Lewis, M. (2000).Teaching collocation: Further developments in the lexical approach. London: Language Teaching Publications.

Liao, E. H. (2010). An investigation of crosslinguistic transfer in EFL learners' phraseology.Alliant International University, San Diego.

Lipske, A. (2006). Teaching Collocations in Foreign Language Classes: Why and How. GRIN Verlag.

Lorenz, G. R. (1999). Adjective Intensification, Learners Versus Native Speakers: A Corpus Study of Argumentative Writing: Rodopi.

Martyska, M. (2004). Do English language learners know collocations? Investigationes linguisticae, 1-12.

McIntosh, M. (1961). Patterns and ranges. Language, 37(3), 325-337.

MihanKhah, F. (1999). Collocations In Persian. Unpublished M. A. thesis.Shiraz University.

Morshali, F. (1995)."A Cross-Sectional Study of the Acquisition of English Lexical Collocations by Iranian EFL Learners.”Unpublished M. A. Thesis.Shiraz Islamic Azad University.

Mitchell, T. F. (1971). Linguistic 'goings-on': Collocations and other lexical matters arising on the syntagmatic record. Archivum Linguisticum, 2(1), 35-69.

Nation, I. S. P. (2001).Learning vocabulary in another language: Cambridge University Press.

Nation, I. S. P. \&Nation, P. (1990).Teaching and learning vocabulary: Heinle \& Heinle.

Nesselhauf, N. (2005). Collocations in a learner corpus: John Benjamins Publishing Company.

Robinson, P. (2001). Individual differences, cognitive abilities, aptitude complexes and learning conditions in second language acquisition.Second Language Research, 17, 368-392.

Sadeghi, K. (2009). Collocational Differences Between L1 and L2: Implications for EFL Learners and Teachers.

TESL Canada Journal.26(2), 100-124.

Sadighi, S. (2012).An Account of English Lexical Collocations Errors through L1Transfer. The Iranian EFL Journal,2(38). 
Shehata, A. K. (2008). L1 Influence on the Reception and Production of Collocations by Advanced ESL/EFL Arabic Learners of English. Ohio University.

Shokouhi, H., \& Mirsalari, GH. (2010). Collocational Knowledge versus General Linguistic Knowledge among Iranian EFL Learners. Teaching English as a Second or foreign language. 13(4), 1-24 http://tesl-

ej.org/pdf/ej52/a7.pdf (September 16, 2010)

Sinclair, J. (1966). Beginning the study of lexis. In J. C. C. C Bazell, M. A. K. Halliday, and R. H. Robins: (Ed.), In Memory of J. R. Firth: Longman.

Sung, J. (2003).English lexical collocations and their relation to spoken fluency of adult non-native speakers. Unpublished doctoral dissertation Indiana University of Pennsylvania, Pennsylvania.

Tajalli, G. (1994). Translatability of English and Persian collocations. Paper presented at the second conference on translation. Tabriz University, Tabriz.

Woolard, G. (2000). Collocation-encouraging learner independence.Teaching collocation: Further developments in the lexical approach, 28-46.

Zhang, X. (1993).English collocations and their effect on the writing of native and non-native college freshmen.Indiana University of Pennsylvania, Pennsylvania.

Zinkgräf, M. (2008). V+ N miscollocations in the written production of university level students. Elia, 8, 91-116. 